\title{
PERCEPCJA ŚRODOWISKOWYCH CZYNNIKÓW JAKOŚCI ŻYCIA NA OBSZARACH WIEJSKICH W WOJEWÓDZTWIE PODKARPACKIM
}

\begin{abstract}
Jakość życia najczęściej interpretowana jest jako stopień zaspokojenia materialnych oraz duchowych potrzeb człowieka. Kształtowana jest przez wiele czynników, z których za najważniejsze uważa się: sytuację mieszkaniową, bezpieczeństwo zatrudnienia, ochronę zdrowia i życia, możliwość uczenia się i podnoszenia kwalifikacji, dostęp do kultury, dostęp do placówek handlowych, stan infrastruktury technicznej czy stopień zaspokojenia indywidualnych potrzeb.

Wieś, przechodząc zmiany związane z postępem cywilizacyjnym, powinna odejść od przypisanych jej w przeszłości stereotypów identyfikujących ją wyłącznie z produkcją rolniczą. Obecnie wieś, oprócz wytwarzania i dostarczania żywności, spełnia także wiele innych funkcji związanych $\mathrm{z}$ ochroną i kształtowaniem krajobrazu i bioróżnorodności, kształtowaniem gospodarki wodnej, zachowaniem wartości dziedzictwa kulturowego tych obszarów. W artykule przedstawiono wyniki badań ankietowych zrealizowanych w $2011 \mathrm{r}$. wśród mieszkańców obszarów wiejskich województwa podkarpackiego. Na subiektywne poczucie jakości życia mogą mieć wpływ takie czynniki jak płeć, wiek osoby, a także kontekst społeczny wynikający na przykład z turystycznego charakteru gminy lub jej położenia względem miast. Wyniki analizowano w podziale na gminy zlokalizowane $\mathrm{w}$ pobliżu miast, oddalone od miast oraz gminy o charakterze turystycznym. W gminach oddalonych od miast doceniano wartość rolniczej przestrzeni produkcyjnej oraz czystość środowiska naturalnego, w gminach zlokalizowanych $\mathrm{w}$ pobliżu miast zaś podkreślano jakość sieci dróg, sieci kanalizacyjnej i wodociągowej oraz wiejski rynek pracy. W gminach zlokalizowanych $\mathrm{z}$ dala od miast obserwowano mniej różnic w ocenie czynników środowiska, co może świadczyć o lokalnej jednolitości postrzegania świata.
\end{abstract}

Słowa kluczowe: jakość życia, obszary wiejskie, czynniki środowiskowe

\section{WSTEP}

Jakość życia może być bardzo różnie postrzegana i interpretowana. Dla różnych grup społecznych jest ona związana $\mathrm{z}$ zaspokojeniem różnorodnych potrzeb materialnych, pewności i stabilizacji życiowej, rozrywki czy potrzeb duchowych. J. Rutkowski ${ }^{3}$ do czynników wpływających na kształtowanie jakości życia zalicza:

1. Czynniki subiektywne - ogólne zadowolenie z życia, oczekiwania, perspektywy na przyszłość, aspiracje.

\footnotetext{
${ }^{1}$ Dr inż. Krzysztof Kud, Katedra Przedsiębiorczości, Zarządzania i Ekoinnowacyjności, Wydział Zarządzania, Politechnika Rzeszowska, al. Powstańców Warszawy 8, 35-959 Rzeszów, tel. (017) 86511 64, e-mail: kkud@prz.edu.pl

${ }^{2}$ Dr inż. Marian Woźniak, Katedra Ekonomii, Wydział Zarządzania, Politechnika Rzeszowska, al. Powstańców Warszawy 8, 35-959 Rzeszów, tel. (017) 86519 03, e-mail: mwozniak@ prz.edu.pl

${ }^{3}$ J. Rutkowski, Jak badać jakość życia, „Wiadomości Statystyczne” 1988/5, s. 42.
} 
2. Czynniki obiektywne - kształtowane przez społeczno-ekonomiczne warunki, w których żyjemy.

Na poziom jakości życia społeczeństwa wiejskiego oraz rozwój obszarów wiejskich wpływają m.in. poziom rozwoju gospodarczego kraju, znaczenie rolnictwa w gospodarce i zatrudnieniu oraz jej wielofunkcyjny charakter. Rozwój jest interpretowany nie tylko jako wzrost gospodarczy i poprawa sytuacji ekonomicznej ludności wiejskiej, ale i jako pojęcie znacznie szersze, dotyczące rozwoju demograficznego, ekonomicznego i społecznego. Powszechnie uznaje się, że wielofunkcyjny rozwój obszarów wiejskich jest ideą aktywizacji wsi i dywersyfikacji działalności gospodarczej, zgodnie z którą przyszłe oblicze wsi i ludności wiejskiej jest związane nie tylko z rolnictwem, ale również z innymi działami gospodarki oraz $\mathrm{z}$ poprawą jakości życia na obszarach wiejskich. Dotyczy to przede wszystkim stworzenia nowych miejsc pracy i przezwyciężenia bezrobocia, aktywowania nowych źródeł zarobkowania $\mathrm{w}$ zawodach związanych $\mathrm{z}$ otoczeniem rolnictwa oraz różnorodności form dochodowego wykorzystania zasobów gospodarstw rolnych i wsi, a także ochroną tych obszarów przed degradacją oraz klęskami żywiołowymi.

W celu zrównoważonego rozwoju obszarów wiejskich istotne jest rozpoznanie oceny przez mieszkańców kluczowych czynników środowiska, a następnie właściwe zarządzanie prowadzące do rozwoju kapitału ekonomicznego i społecznego z poszanowaniem przyrody. Obszary wiejskie wymagają kompleksowej, gruntownej modernizacji mającej na uwadze dobro lokalnych społeczności. W praktyce oznacza to konieczność identyfikacji problemów i oczekiwań oraz indywidualnego podejścia. Współcześnie wśród populacji zamieszkującej wieś, mimo że w znacznym stopniu zróżnicowanej, to jedynie jedna trzecia utrzymuje się z rolnictwa ${ }^{4}$. Jednocześnie rolnictwo z natury rzeczy użytkuje środowisko i to właśnie ono powinno stać na straży przyrody. Jego rola obejmuje nie tylko produkcję artykułów żywnościowych oraz surowców, ale również zachowanie bogactwa krajobrazu przyrodniczego oraz kulturowego, jednocześnie stwarzając warunki dobrej jakości życia ${ }^{5}$.

W pracy podjęto próbę identyfikacji oceny wybranych elementów środowiska życia przez społeczności wiejskie $\mathrm{w}$ województwie podkarpackim. Taka ocena pozwoli na określenie odbioru społecznego obecnego stanu jakości życia oraz powinna dać obraz oczekiwań społeczności lokalnej w tym zakresie.

\section{CEL I METODYKA}

Celem artykułu jest przedstawienie czynników wpływających na jakość życia społeczeństwa wiejskiego, ze szczególnym uwzględnieniem wsi podkarpackiej. W artykule przedstawiono wyniki badań ankietowych zrealizowanych w 2011 r. wśród 1130 osób zamieszkujących obszary wiejskie Podkarpacia. W artykule przeprowadzono analizę oceny czynników środowiska życia ludności, skupiono się głównie na czynnikach subiektywnych kształtujących jakość życia.

\footnotetext{
${ }^{4}$ Forum Debaty Publicznej, Polska wieś 2012, Potencjat obszarów wiejskich szansa rozwoju, „Biuletyn Forum Debaty Publicznej” 2013/23, Kancelaria Prezydenta Rzeczypospolitej Polskie, Warszawa 2013, s. 9

${ }^{5}$ K. Kud, L. Woźniak, Proekologiczna restrukturyzacja gospodarki żywnościowej jako czynnik innowacji, „Prace Naukowe AE we Wrocławiu” 2004/1030, s. 608-614.
} 
Zgromadzony materiał poddano analizie statystycznej w celu znalezienia prawidłowości w postrzeganiu wpływu czynników środowiska na jakość życia mieszkańców. Porównano odpowiedzi w grupach socjodemograficznych oraz badane gminy podzielono na trzy typy, w których za kryterium podziału przyjęto oddalenie od ośrodków miejskich (2 grupy - leżące blisko i oddalone od miasta) oraz turystyczny charakter gminy. Porównanie wykonano za pomocą jednoczynnikowej analizy wariancyjnej. ${ }^{6}$. Hipotezę zerową o równości wartości oczekiwanych badano testem $\mathrm{F}$ Fishera-Snedecora. Dalszą analizę - post hoc - wykonywano testem NIR Tukeya.

\section{CHARAKTERYSTYKA WOJEWÓDZTWA PODKARPACKIEGO}

Według danych z 2011 r. województwo podkarpackie, zlokalizowane w południowowschodniej części Polski, zajmuje powierzchnię $17846 \mathrm{~km}^{2}$, co stanowi 5,7\% ogólnej powierzchni Polski. Obszar ten zamieszkuje 2022 tys. osób, czyli 5,3\% ludności kraju. Gęstość zaludnienia wynosi 113 osób na $1 \mathrm{~km}^{2}$, co plasuje województwo na dziewiątej pozycji w kraju. Większość ludności $(58,5 \%)$ zamieszkuje tereny wiejskie województwa. Województwo podkarpackie dzieli się na cztery podregiony: krośnieński, przemyski, rzeszowski, tarnobrzeski, skupiających 160 gmin oraz 21 powiatów (rys. 1).

Województwo podkarpackie ma dodatni przyrost naturalny $(+1,4)$ oraz ujemne saldo migracji wewnętrznych $(-1,0)$. W województwie odnotowano jedną z największych stóp bezrobocia w kraju, sięgającą 12,5\%, co daje niestety, przy średniej krajowej 9,7\%, drugą pozycję w kraju. W województwie odnotowano również największy w kraju wzrost cen towarów i usług konsumpcyjnych, sięgający 4,9\%. Wartość skupu produktów rolnych, na poziomie 377 zł produktów roślinnych i 641 zł produktów zwierzęcych na 1 ha użytków rolnych, umiejscawia województwo znacznie poniżej średniej krajowej, w dolnej części hierarchii województw w kraju?

$\mathrm{Na}$ początku XXI wieku województwo podkarpackie nadal można określić jako wiejskie. O jego wiejskim charakterze świadczy znaczny odsetek gmin wiejskich, które stanowią ponad $70 \%$ spośród wszystkich gmin województwa. Około $60 \%$ ludności żyje na obszarach wiejskich. Jednocześnie średnia wielkość gospodarstwa rolnego wynosi tylko 2,63 ha (średnia w Polsce to 6,82 ha), co powoduje przeludnienie tych obszarów oraz stanowi znaczny problem strukturalny $\mathrm{w}$ stosunku do rozwoju i modernizacji regionu. Województwo podkarpackie, $\mathrm{w}$ porównaniu $\mathrm{z}$ innymi częściami kraju, charakteryzuje się odmiennymi warunkami gospodarowania, które wynikają ze zróżnicowanych warunków przyrodniczych, społeczno-gospodarczych, ekonomicznych, a także historycznych. Na podstawie potencjalnych warunków i czynników rozwoju wykształciły się trzy podstawowe funkcje województwa: rolnicza, przemysłowa oraz turystyczno-rekreacyjna ${ }^{8}$.

\footnotetext{
${ }^{6}$ A. Luszniewicz, T. Słaby, Statystyka. Teoria i zadania, C.H. Beck, Warszawa 2001.

${ }^{7}$ Raport o sytuacji społeczno-gospodarczej województwa podkarpackiego 2011, Urząd Statystyczny w Rzeszowie, Rzeszów 2012, s. 17-21.

${ }^{8}$ P. Grygiel, A. Grzesik, Społeczno-gospodarcza kondycja województwa Podkarpackiego na tle kraju, [w:] Województwo podkarpackie na początku XXI wieku. Studia socjologiczne, red. M. Malikowski, MANA, Rzeszów 2003, s. 58-60.
} 
Rys. 1. Podział województwa podkarpackiego według nomenklatury NTS w 2012 r.
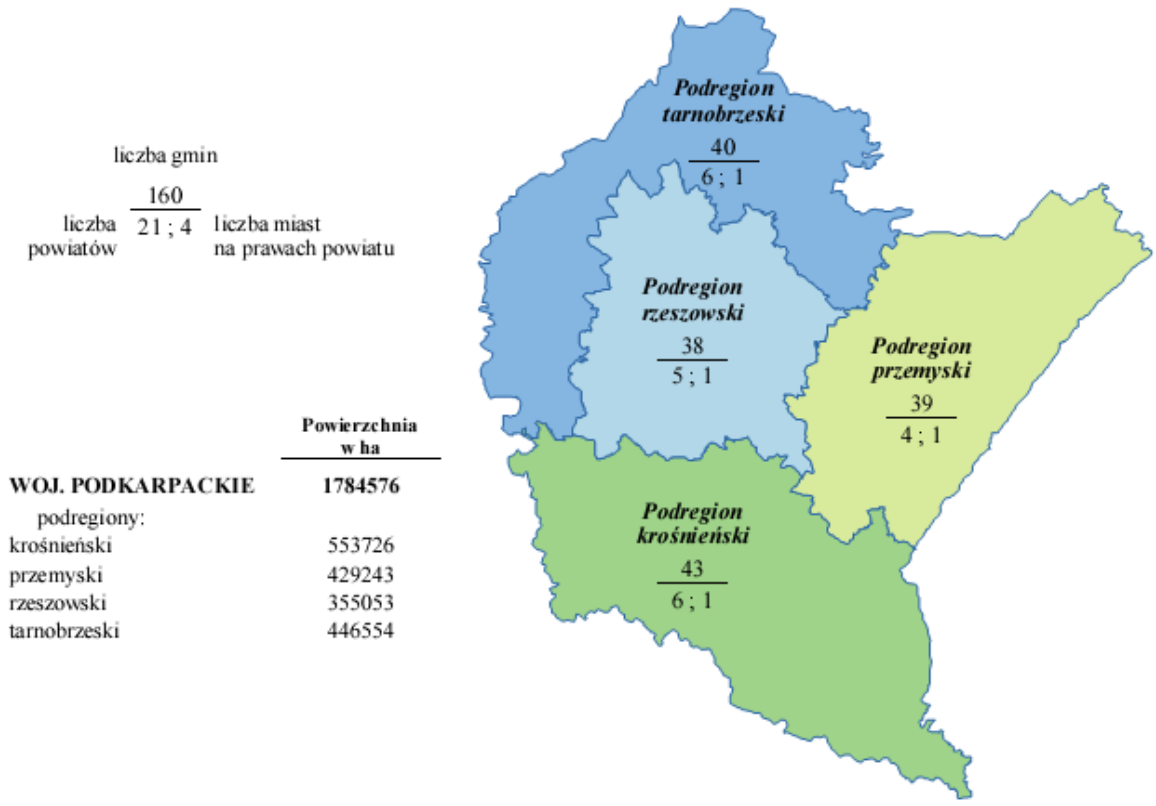

Źródło: Raport o sytuacji społeczno-gospodarczej województwa podkarpackiego 2011, Urząd Statystyczny w Rzeszowie, Rzeszów 2012, s. 21.

Koncepcją, która uwzględnia poprawę jakości życia na obszarach wiejskich, jest jej wielofunkcyjny rozwój, który zakłada gospodarczą aktywizację wsi poprzez tworzenie nowych miejsc pracy poza rolnictwem. Wieś przestanie być wówczas postrzegana jedynie w swej tradycyjnej roli, polegającej na produkcji żywności, a stanie się miejscem świadczenia usług oraz działalności produkcyjno-handlowej (niekoniecznie związanej z rolnictwem) ${ }^{9}$. Wielofunkcyjny rozwój terenów wiejskich polega głównie na znacznie większym niż dotychczas różnicowaniu obszarów wiejskich, a więc odejściu od monofunkcyjności, polegającej z reguły na produkcji surowców rolniczych i umiejętnym wkomponowaniu w wiejską przestrzeń coraz to nowych funkcji pozarolniczych ${ }^{10}$.

\footnotetext{
${ }^{9}$ A. Kobiałka, Rola gminy w rozwoju obszarów wiejskich, [w:] Strategie rozwoju lokalnego. Aspekty instytucjonalne, red. M. Adamowicz, t. I, Szkoła Główna Gospodarstwa Wiejskiego, Warszawa 2003, s. 66.

${ }^{10}$ M. Kłodziński, Wielofunkcyjny rozwój terenów wiejskich w Polsce i w krajach UE, SGGW, Warszawa 1996, s. 11.
} 


\section{JAKOŚĆ ŻYCIA W ROZWOJU ZRÓWNOWAŻONYM I TRWAEYM}

Prace naukowe dotyczące rozwoju zrównoważonego w Polsce prowadzone są od lat siedemdziesiątych XX wieku i badania te przechodziły różne etapy: od inspiracji, przez dojrzewanie, fascynację, implementację, aż do wątpliwości ${ }^{11}$. Idea rozwoju zrównoważonego i trwałego jest różnie definiowana. Piontek i Piontek ${ }^{12}$ twierdzą, że rozwój zrównoważony i trwały polega na trwałej poprawie jakości życia współczesnych i przyszłych pokoleń poprzez kształtowanie właściwych proporcji między trzema rodzajami kapitału: ekonomicznym, ludzkim i przyrodniczym. Autorzy ci podkreślają, że w relacjach wymienionych kapitałów jakość życia pełni funkcje kryterialne i integrujące. Zatem to jakość życia, rozumiana jako kształtowanie właściwych proporcji w generowaniu, zaspokajaniu i sposobach realizacji potrzeb ekonomicznych, społecznych, przyrodniczych i duchowych na podstawie funkcji kryterialnych sfery moralnej, jest istotą rozwoju zrównoważonego i trwałego. Papuziński ${ }^{13} \mathrm{w}$ ujęciu syntetycznym podaje, że rozwój zrównoważony to rozwój zakładający równowagę między wzrostem gospodarczym a stanem ekosystemów w celu zapewnienia społeczeństwu wysokiej jakości życia.

\section{CZYNNIKI ŚRODOWISKOWE KSZTALTUJĄCE JAKOŚĆ ŻYCIA W OPINII MIESZKAŃCÓW WSI WOJEWÓDZTWA PODKARPACKIEGO}

Oceniając czynniki wpływające na jakość życia społeczności wiejskiej, analizie poddano głównie elementy techniczne, społeczne oraz środowiska naturalnego obszarów wiejskich. Na rysunku 2 przedstawiono oceny poszczególnych czynników środowiska życia ludności zgrupowane dla wszystkich respondentów.

Wysoko oceniono system telekomunikacyjny oraz walory krajobrazowe. Te czynniki uzyskały ponad $60 \%$ ocen bardzo dobrych i dobrych. Wysokie oceny uzyskały również czystość powietrza, system szkolnictwa, czystość wizualna wsi, bezpieczeństwo, sieć kanalizacyjno-wodociągowa oraz czystość gleb. Znaczny odsetek ocen przeciętnych uzyskały: jakość rolniczej przestrzeni produkcyjnej, poziom zaangażowania społecznego mieszkańców, standard i jakość życia mieszkańców.

Najgorzej oceniono wiejski rynek pracy, gdyż 60\% respondentów określiło go źle lub bardzo źle. Również blisko połowa respondentów ma negatywne zdanie o sieci dróg, usługach turystycznych, usługach bankowych oraz usługach gastronomicznych.

Obraz wynikający z tej oceny był niejednoznaczny - respondenci lepiej oceniają czynniki związane z potencjałem środowiska naturalnego, gorzej jednak sferę usług i zatrudnienia.

\footnotetext{
${ }^{11}$ T. Borys, S. Czaja, Badania nad Zrównoważonym Rozwojem w Polskich Ośrodkach Naukowych, [w:] Od koncepcji ekorozwoju do ekonomii zrównoważonego rozwoju, red. D. Kiełczewski, Wydawnictwo Wyższej Szkoły Ekonomicznej w Białymstoku, Białystok 2009, s. 51-74.

${ }^{12}$ F. Piontek, B. Piontek, Najlepsze dostępne techniki (BAT) i Mnożnik Cztery dla zapewnienia ochrony środowiska, Rocznik Ochrony Srodowiska, Wydawnictwo Środowisko-Pomorskiego Tow. Nauk. Ochr. Środ., t. IV, Koszalin 2002, s. 49-74.

${ }^{13}$ A. Papuziński, Filozoficzne aspekty zrównoważonego rozwoju - wprowadzenie, „Problemy Ekorozwoju" 1/2, Lublin 2006, s. 25-32.
} 
Rys. 2. Ocena wybranych czynników środowiska dokonana przez mieszkańców wsi województwa podkarpackiego

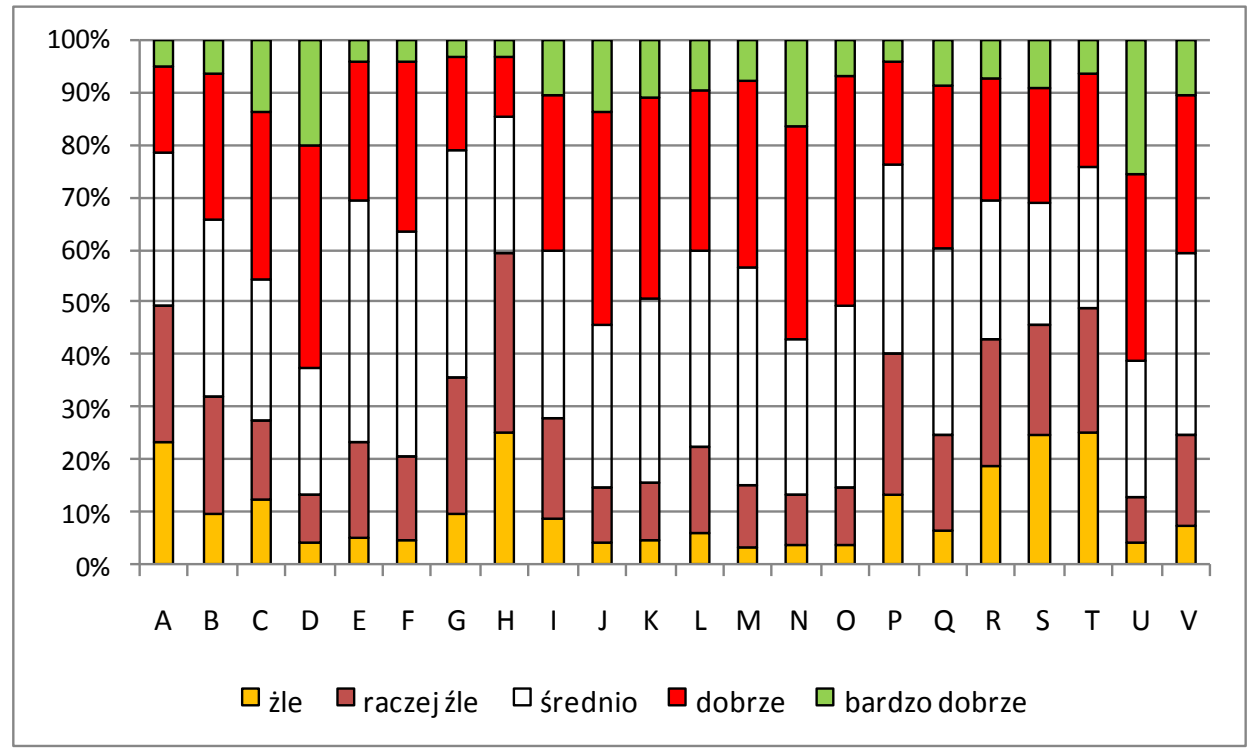

A - sieć dróg; B - usługi komunikacyjne; C - sieć kanalizacyjna i wodociągowa; D - system telekomunikacyjny (telefony, Internet); $\mathbf{E}$ - jakość rolniczej przestrzeni produkcyjnej; $\mathbf{F}$ - standard i jakość życia mieszkańców; $\mathbf{G}$ - poziom zaangażowania społecznego mieszkańców; $\mathbf{H}$ - wiejski rynek pracy; I - usługi lecznicze (ośrodki zdrowia, apteki); J - system szkolnictwa; K bezpieczeństwo; $\mathbf{L}$ - czystość wód; $\mathbf{M}$ - czystość gleb; $\mathbf{N}$ - czystość powietrza; $\mathbf{O}$ - czystość wizualna wsi; $\mathbf{P}$ - oferta kulturalna; $\mathbf{Q}$ - usługi handlowe; $\mathbf{R}$ - usługi gastronomiczne; $\mathbf{S}$ - usługi bankowe; $\mathbf{T}$ - usługi turystyczne (baza, informacja turystyczna, oznaczenia szlaków); $\mathbf{U}$ - walory krajobrazowe; $\mathbf{V}$ - walory kulturowe

Źródło: obliczenia własne

W tabeli 1 przedstawiono czynniki, na których postrzeganie ma istotny statystycznie wpływ typ gminy (położone przy mieście, położone $\mathrm{z}$ dala od miasta oraz gminy o charakterze turystycznym). Zamieszczono średnią ocen, wartość testu $F$ oraz graniczny poziom błędu, przy którym zależność była statystycznie istotna.

Z przeprowadzonych analiz wynika, że mieszkańcy gmin położonych przy mieście wyżej oceniają sieć dróg, sieć kanalizacyjną i wodociągową oraz wiejski rynek pracy. Jakość rolniczej przestrzeni produkcyjnej była istotnie najwyższa wśród mieszkańców gmin położonych $\mathrm{z}$ dala od miasta, a istotnie najniższa wśród mieszkańców gmin o turystycznym charakterze. Oceny te są zbieżne $\mathrm{z}$ wykorzystaniem przestrzeni, gdyż krajobraz o wysokich walorach estetycznych zazwyczaj jest zachowany w rejonach mało przekształconych antropogenicznie. 
Najwyższe oceny czynników związanych ze środowiskiem naturalnym (czystość wód, gleb i powietrza) stwierdzono $w$ gminach położonych $\mathrm{z}$ dala od miast, a najniższe położone przy miastach. Zależność ta wydaje się oczywista, gdyż aglomeracje miejskie są związane ze wzrostem zanieczyszczenia. Walory kulturowe oraz usługi turystyczne najwyżej oceniają mieszkańcy gmin o turystycznym charakterze, najniżej zaś położonych przy miastach. Ocena walorów krajobrazu była istotnie wyższa wśród mieszkańców gmin położonych $\mathrm{z}$ dala od miasta i o charakterze turystycznym w porównaniu z opinią mieszkańców gmin położonych przy mieście.

Tabela 1. Wpływ typu gminy na dokonaną przez mieszkańców ocenę czynników środowiska

\begin{tabular}{|c|c|c|c|c|c|}
\hline \multirow[b]{2}{*}{$\begin{array}{l}\text { Element } \\
\text { środowiska }\end{array}$} & \multicolumn{3}{|c|}{ Typ gminy } & \multirow[b]{2}{*}{$\mathbf{F}$} & \multirow[b]{2}{*}{$\mathbf{p}_{\text {gran }}$} \\
\hline & $\begin{array}{c}\text { a. } \\
\text { położona } \\
\text { przy mieście }\end{array}$ & $\begin{array}{c}\text { b. } \\
\text { polożona } \\
\text { z dala od } \\
\text { miasta }\end{array}$ & $\begin{array}{l}\text { c. } \\
\text { o charakterze } \\
\text { turystycznym }\end{array}$ & & \\
\hline Sieć dróg & $2,64 \mathrm{~b}$ & $2,45 \mathrm{a}$ & $2,49 \mathrm{a}$ & 4,02 & 0,018 \\
\hline $\begin{array}{l}\text { Sieć kanalizacyjna i } \\
\text { wodociągowa }\end{array}$ & $3,31 \mathrm{~b}$ & $3,10 \mathrm{a}$ & $3,15 \mathrm{a}$ & 4,27 & 0,014 \\
\hline $\begin{array}{l}\text { Jakość rolniczej } \\
\text { przestrzeni } \\
\text { produkcyjnej }\end{array}$ & $3,05 \mathrm{ab}$ & $3,15 \mathrm{~b}$ & $2,93 \mathrm{a}$ & 5,40 & 0,005 \\
\hline Wiejski rynek pracy & $2,45 \mathrm{~b}$ & $2,26 \mathrm{a}$ & $2,22 \mathrm{a}$ & 5,86 & 0,003 \\
\hline Czystość wód & $3,14 \mathrm{a}$ & $3,29 \mathrm{~b}$ & $3,23 \mathrm{ab}$ & 3,01 & 0,049 \\
\hline Czystość gleb & $3,25 \mathrm{a}$ & $3,43 \mathrm{~b}$ & $3,33 \mathrm{ab}$ & 5,27 & 0,005 \\
\hline Czystość powietrza & $3,39 \mathrm{a}$ & $3,77 \mathrm{~b}$ & $3,52 \mathrm{ab}$ & 20,17 & 0,000 \\
\hline $\begin{array}{l}\text { Usługi turystyczne } \\
\text { (baza, informacja } \\
\text { turystyczna, } \\
\text { oznaczenia szlaków) }\end{array}$ & $2,60 \mathrm{~b}$ & $2,43 \mathrm{a}$ & $2,81 \mathrm{c}$ & 8,23 & 0,000 \\
\hline $\begin{array}{l}\text { Walory } \\
\text { krajobrazowe }\end{array}$ & $3,57 \mathrm{a}$ & $3,79 \mathrm{~b}$ & $3,81 \mathrm{~b}$ & 7,41 & 0,001 \\
\hline Walory kulturowe & $3,10 \mathrm{a}$ & $3,24 \mathrm{ab}$ & $3,33 \mathrm{~b}$ & 4,90 & 0,008 \\
\hline
\end{tabular}

Jednakowy symbol literowy przy wartościach średniej oznacza brak istotnych różnic w teście NIR Źródło: obliczenia własne

W tabeli 2 zamieszczono wyniki analizy, w której zmienną niezależną była płeć respondentów. Oprócz obiektywnych czynników środowiska, składających się na jakość życia mieszkańców, istotne jest ich subiektywne postrzeganie. W celu poznania różnic w odbiorze rzeczywistości wyniki poddano analizie z uwzględnieniem płci oraz wieku respondentów. Stąd analiza wariancji, przeprowadzona dla wszystkich respondentów niezależnie od typu gminy, wykazała istotny statystycznie wpływ płci na ocenę: systemu telekomunikacyjnego, czystości wód, czystości wizualnej wsi, usług handlowych, walorów kulturowych, natomiast ocena pozostałych czynników nie zależy od płci. Ocena czynnika czystości wód była wyższa wśród mężczyzn, pozostałe wymienione czynniki wyżej oceniały kobiety. 
Tabela 2. Wpływ płci respondentów na dokonaną ocenę czynników środowiska

\begin{tabular}{|c|c|c|c|c|}
\hline \multirow{2}{*}{ Element środowiska } & \multicolumn{2}{|c|}{ Pleć } & \multirow{2}{*}{$\mathbf{F}$} & \multirow{2}{*}{ pgran } \\
\hline & Kobiety & Mężczyźni & & \\
\hline \multicolumn{5}{|c|}{ Wszyscy respondenci } \\
\hline $\begin{array}{l}\text { System telekomunikacyjny (telefony, } \\
\text { Internet) }\end{array}$ & 3,72 & 3,58 & 5,81 & 0,016 \\
\hline Czystość wód & 3,14 & 3,30 & 7,56 & 0,006 \\
\hline Czystość wizualna wsi & 3,46 & 3,33 & 7,19 & 0,007 \\
\hline Usługi handlowe & 3,23 & 3,10 & 5,20 & 0,023 \\
\hline Walory kulturowe & 3,26 & 3,12 & 5,40 & 0,02 \\
\hline \multicolumn{5}{|c|}{ Gminy położone przy mieście } \\
\hline Usługi komunikacyjne & 3,20 & 2,87 & 14,63 & 0,0 \\
\hline $\begin{array}{l}\text { System telekomunikacyjny (telefony, } \\
\text { Internet) }\end{array}$ & 3,77 & 3,54 & 7,83 & 0,005 \\
\hline $\begin{array}{l}\text { Poziom zaangażowania społecznego } \\
\text { mieszkańców }\end{array}$ & 2,88 & 2,71 & 4,52 & 0,034 \\
\hline Czystość wód & 3,06 & 3,24 & 4,79 & 0,029 \\
\hline Czystość powietrza & 3,48 & 3,29 & 4,99 & 0,026 \\
\hline Czystość wizualna wsi & 3,55 & 3,24 & 17,17 & 0,0 \\
\hline Usługi handlowe & 3,27 & 3,07 & 5,59 & 0,018 \\
\hline Walory krajobrazowe & 3,70 & 3,4 & 9,94 & 0,002 \\
\hline Walory kulturowe & 3,20 & 2,97 & 6,69 & 0,01 \\
\hline \multicolumn{5}{|c|}{ Gminy położone $\mathrm{z}$ dala od miasta } \\
\hline Standard i jakość życia mieszkańców & 3,09 & 3,24 & 3,92 & 0,048 \\
\hline \multicolumn{5}{|c|}{ Gminy o charakterze turystycznym } \\
\hline Sieć dróg & 2,34 & 2,69 & 4,24 & 0,041 \\
\hline Sieć kanalizacyjna i wodociągowa & 2,97 & 3,38 & 6,96 & 0,009 \\
\hline Czystość powietrza & 3,39 & 3,67 & 4,58 & 0,033 \\
\hline
\end{tabular}

Źródło: obliczenia własne

Analiza wariancji, w której określano wpływ płci na ocenę czynników środowiska, przeprowadzono również w poszczególnych, wydzielonych typach gmin (tab. 2). W gminach położonych przy mieście obliczono istotny statystycznie wpływ płci na ocenę następujących czynników: usługi komunikacyjne, system telekomunikacyjny, poziom zaangażowania społecznego mieszkańców, czystość wód, powietrza, czystość wizualna wsi, usługi handlowe, walory krajobrazowe. Warto podkreślić, że wszystkie oceny były wyższe wśród kobiet. Być może wiąże się to ze zmianą tradycyjnej roli kobiet, które podejmując pracę zawodową i konkurencję z mężczyznami w obszarach wcześniej dla nich niedostępnych, wykazują większy optymizm. Może to jednak wynikać z większego zapotrzebowania na optymizm w trudnym procesie wychowania potomstwa. 
$\mathrm{W}$ gminach położonych $\mathrm{z}$ dala od miast statystycznie istotny wpływ płci obliczono jedynie dla czynnika standard i jakość życia mieszkańców. Ten czynnik wyżej ocenili mężczyźni. W gminach o charakterze turystycznym płeć respondentów miała istotny wpływ na ocenę sieci dróg, sieci kanalizacyjnej i wodociągowej oraz czystości powietrza. Wszystkie te czynniki wyżej ocenili mężczyźni.

Przeprowadzono również analizę wpływu wieku respondentów na ocenę czynników środowiska życia, wyniki istotne statystycznie zamieszczono w tabeli 3.

Tabela 3. Wpływ wieku respondentów na dokonaną ocenę czynników środowiska

\begin{tabular}{|c|c|c|c|c|c|c|c|}
\hline \multirow{2}{*}{ Element środowiska } & \multicolumn{5}{|c|}{ Wiek } & \multirow{2}{*}{$\mathbf{F}$} & \multirow{2}{*}{$\mathbf{p}_{\text {gran }}$} \\
\hline & 15-18 & 19-25 & $26-35$ & $36-50$ & $>50$ lat & & \\
\hline \multicolumn{8}{|c|}{ Wszyscy respondenci } \\
\hline $\begin{array}{l}\text { Sieć kanalizacyjna i } \\
\text { wodociągowa }\end{array}$ & $3,08 \mathrm{a}$ & $3,16 \mathrm{a}$ & $3,31 \mathrm{~b}$ & $3,09 \mathrm{a}$ & $3,38 b$ & 2,92 & 0,02 \\
\hline $\begin{array}{l}\text { Standard i jakość życia } \\
\text { mieszkańców }\end{array}$ & $3,25 b$ & $3,23 b$ & $3,18 \mathrm{ab}$ & $3,10 \mathrm{a}$ & $3,03 \mathrm{a}$ & 2,55 & 0,038 \\
\hline Wiejski rynek pracy & $2,55 \mathrm{~b}$ & $2,45 b$ & $2,29 a$ & $2,23 \mathrm{a}$ & $2,25 \mathrm{a}$ & 3,80 & 0,004 \\
\hline Bezpieczeństwo & $3,64 b$ & $3,40 \mathrm{a}$ & $3,39 \mathrm{a}$ & $3,38 \mathrm{a}$ & $3,27 \mathrm{a}$ & 3,13 & 0,014 \\
\hline Usługi handlowe & $3,01 \mathrm{a}$ & $3,16 a b$ & $3,10 \mathrm{ab}$ & $3,20 b$ & $3,35 \mathrm{c}$ & 2,83 & 0,024 \\
\hline \multicolumn{8}{|c|}{ Gminy położone przy mieście } \\
\hline $\begin{array}{l}\text { Sieć kanalizacyjna i } \\
\text { wodociągowa }\end{array}$ & $3,25 \mathrm{c}$ & $3,37 \mathrm{c}$ & $3,29 \mathrm{c}$ & $3,09 \mathrm{~b}$ & $3,62 \mathrm{a}$ & 2,88 & 0,022 \\
\hline $\begin{array}{l}\text { System } \\
\text { telekomunikacyjny } \\
\text { (telefony, Internet) }\end{array}$ & $3,84 b$ & $3,86 \mathrm{~b}$ & $3,53 \mathrm{a}$ & $3,50 \mathrm{a}$ & $3,67 a b$ & 3,34 & 0,01 \\
\hline $\begin{array}{l}\text { Standard i jakość życia } \\
\text { mieszkańców }\end{array}$ & $3,23 b$ & $3,28 b$ & $3,26 b$ & $3,15 \mathrm{ab}$ & $2,92 \mathrm{a}$ & 2,78 & 0,026 \\
\hline \multicolumn{8}{|c|}{ Gminy położone $\mathrm{z}$ dala od miasta } \\
\hline Bezpieczeństwo & $3,91 b$ & $3,46 \mathrm{a}$ & $3,45 \mathrm{a}$ & $3,39 \mathrm{a}$ & $3,34 \mathrm{a}$ & 3,40 & 0,009 \\
\hline Czystość wizualna wsi & $3,70 b$ & $3,43 \mathrm{a}$ & $3,28 \mathrm{a}$ & $3,39 \mathrm{a}$ & $3,31 \mathrm{a}$ & 2,44 & 0,046 \\
\hline \multicolumn{8}{|c|}{ Gminy o charakterze turystycznym } \\
\hline Sieć dróg & $2,31 \mathrm{a}$ & $2,18 \mathrm{a}$ & $2,61 b$ & $2,27 \mathrm{a}$ & $3,09 \mathrm{c}$ & 4,21 & 0,003 \\
\hline Czystość powietrza & $3,56 b$ & $3,60 \mathrm{~b}$ & $3,82 \mathrm{c}$ & $3,39 \mathrm{a}$ & $3,21 \mathrm{a}$ & 2,67 & 0,033 \\
\hline Usługi handlowe & $2,75 \mathrm{a}$ & $3,18 b$ & $3,04 \mathrm{ab}$ & $2,90 \mathrm{ab}$ & $3,60 \mathrm{c}$ & 3,00 & 0,019 \\
\hline Usługi gastronomiczne & $2,75 b$ & $3,15 \mathrm{c}$ & $3,06 \mathrm{c}$ & $2,43 \mathrm{a}$ & $2,81 \mathrm{~b}$ & 3,32 & 0,011 \\
\hline
\end{tabular}

Jednakowy symbol literowy przy wartościach średniej oznacza brak istotnych różnic w teście NIR Źródło: obliczenia własne

Analiza wariancji wykazała istotny statystycznie wpływ wieku na ocenę następujących czynników: sieć kanalizacyjna i wodociągowa, standard i jakość życia mieszkańców, wiejski rynek pracy, bezpieczeństwo, usługi handlowe. Ocena pozostałych czynników natomiast nie zależała od wieku. Ocena sieci kanalizacyjnej i wodociągowej była istotnie 
wyższa wśród respondentów grupy wiekowej 26-35 i powyżej 50 lat w porównaniu z pozostałymi grupami wiekowymi. Ocena standardu i jakości życia mieszkańców była wyższa wśród młodych ludzi; statystycznie istotnie najwyższa wśród respondentów grupy wiekowej 15-18 i 19-25 lat, a najniższa - wśród respondentów grupy wiekowej 36-50 i powyżej 50 lat. Ocena wiejskiego rynku pracy była istotnie wyższa wśród młodszych respondentów $\mathrm{w}$ wieku 15-18 i 19-25 lat $\mathrm{w}$ porównaniu $\mathrm{z}$ pozostałymi grupami wiekowymi. Może to wynikać z faktu, że młodzi ludzie jeszcze się uczą i nie zapoznali się ze specyfiką tego rynku. Ocena obszaru bezpieczeństwo była istotnie wyższa wśród respondentów $\mathrm{w}$ wieku 15-18 lat w porównaniu $\mathrm{z}$ pozostałymi grupami wiekowymi, ocena usług handlowych zaś była istotnie najwyższa wśród respondentów grupy wiekowej powyżej 50 lat, a istotnie najniższa - wśród respondentów grupy wiekowej 15-18 lat, co prawdopodobnie wiąże się ze zmianą pokoleniową i doświadczeniami osób w wieku , $50+”$.

W gminach położonych przy mieście ocena sieci kanalizacyjnej i wodociągowej najwyżej oceniły osoby powyżej 50. roku życia, system telekomunikacyjny wyżej oceniali ludzie młodzi, standard i jakość życia mieszkańców zaś najniżej oceniali respondenci z najstarszej grupy wiekowej.

$\mathrm{W}$ gminach położonych $\mathrm{z}$ dala od miasta istotny statystycznie wpływ wieku obliczono jedynie dla oceny bezpieczeństwa oraz czystości wizualnej wsi. Te czynniki najwyżej oceniały osoby w wieku 15-18 lat. Sytuacja taka może świadczyć o podobnym, niezależnie od wieku pojmowaniu rzeczywistości przez osoby mieszkające $\mathrm{z}$ dala od miast.

W gminach o charakterze turystycznym w ocenie czynników związanych z usługami pojawiły się różnice związane $\mathrm{z}$ wiekiem. Takie zróżnicowanie może wskazywać na troskę społeczności lokalnych o warunki sprzyjające turystyce. Wiek wpływał na ocenę sieci dróg, czystości powietrza, usług handlowych i usług gastronomicznych. Sieć dróg i usługi handlowe najwyżej oceniali respondenci w wieku powyżej 50 lat. Czystość powietrza i usługi gastronomiczne najwyżej oceniły osoby w wieku 26-35 lat.

\section{ZAKOŃCZENIE}

Jakość życia w rozwoju zrównoważonym wynika ze zrównoważenia podstawowych sfer: społecznej, ekonomicznej i przyrodniczej. Dążenie do podnoszenia jakości życia lokalnych społeczności polega na osiągnięciu określonego, pożądanego stanu (benchmarku) w podstawowych obszarach: ładu społecznego, ładu gospodarczego i ładu środowiskowo-przestrzennego. Jednak subiektywne poczucie, doświadczenie, jakości życia jest zjawiskiem złożonym wynikającym z indywidualnych doświadczeń, ambicji, relacji, dążeń oraz środowiska kulturowego, gospodarczego oraz środowiska naturalnego.

Na podstawie przeprowadzonej analizy można stwierdzić, że na subiektywne poczucie jakości życia mogą mieć wpływ takie czynniki, jak płeć, wiek osoby i kontekst społeczny wynikający na przykład z turystycznego charakteru gminy lub jej położenia względem miast. W gminach o charakterze turystycznym podkreślano czynniki wspierające turystykę, takie jak walory krajobrazowe, kulturowe oraz usługi turystyczne. W gminach oddalonych od miast doceniano wartość rolniczej przestrzeni produkcyjnej oraz czystość środowiska naturalnego, w gminach zlokalizowanych $\mathrm{w}$ pobliżu miast zaś podkreślano jakość sieci dróg, sieci kanalizacyjnej i wodociągowej oraz wiejski rynek pracy. 
W gminach zlokalizowanych $\mathrm{z}$ dala od miast obserwowano mniej różnic w ocenie czynników środowiska, co może świadczyć o jednoznacznym charakterze badanych zjawisk lub o lokalnej jednolitości postrzegania świata. Taka jednomyślność może mieć bardzo istotne znaczenie w pokonywaniu trudności i zagrożeń lokalnych społeczności, może być ważnym atutem w budowaniu partycypacyjnego modelu zarządzania w gminie. Jednocześnie może stanowić poważną barierę we wprowadzaniu pozytywnych zmian wymagających odrzucenia dotychczasowego modelu niewłaściwego postępowania, a w takiej sytuacji inercja społeczna może działać wysoce negatywnie.

Zdaniem autorów, istotnym zagadnieniem wymagającym dalszych badań są elementy kształtujące percepcję środowiskowych czynników jakości życia.

\section{LITERATURA}

[1] Borys T., Czaja S., Badania nad Zrównoważonym Rozwojem w Polskich Ośrodkach Naukowych, [w:] Od koncepcji ekorozwoju do ekonomii zrównoważonego rozwoju, red. D. Kiełczewski, Wydawnictwo Wyższej Szkoły Ekonomicznej w Białymstoku, Białystok 2009.

[2] Forum Debaty Publicznej, Polska wieś 2012. Potencjał obszarów wiejskich szansq rozwoju, „Biuletyn Forum Debaty Publicznej” 2013/23, Kancelaria Prezydenta Rzeczypospolitej Polskiej, Warszawa 2013,

[3] Grygiel P., Grzesik A., Społeczno-gospodarcza kondycja województwa Podkarpackiego na tle kraju, [w:] Województwo podkarpackie na początku XXI wieku. Studia socjologiczne, red. M. Malikowski, MANA, Rzeszów 2003.

[4] Kłodziński M., Wielofunkcyjny rozwój terenów wiejskich $w$ Polsce i w krajach UE, SGGW, Warszawa 1996.

[5] Kobiałka A., Rola gminy w rozwoju obszarów wiejskich, [w:] Strategie rozwoju lokalnego. Aspekty instytucjonalne, red. M. Adamowicz, t. I, Szkoła Główna Gospodarstwa Wiejskiego, Warszawa 2003.

[6] Kud K., Woźniak L., Proekologiczna restrukturyzacja gospodarki żywnościowej jako czynnik innowacji, „Prace Nauk. AE we Wrocławiu” 2004/1030, s. 608614.

[7] Luszniewicz A., Słaby T., Statystyka. Teoria i zadania, C.H. Beck, Warszawa 2001.

[8] Papuziński A., Filozoficzne aspekty zrównoważonego rozwoju - wprowadzenie, „Problemy Ekorozwoju” 1/2 (2006).

[9] Piontek F., Piontek B., Najlepsze dostepne techniki (BAT) i Mnożnik Cztery dla zapewnienia ochrony środowiska, „Rocznik Ochrony Środowiska”, Wydawnictwo Środowisko-Pomorskiego Tow. Nauk. Ochr. Środ., t. IV, Koszalin 2002.

[10] Raport o sytuacji społeczno-gospodarczej województwa podkarpackiego 2011, Urząd Statystyczny w Rzeszowie, Rzeszów 2012.

[11] Rutkowski J., Jak badać jakość życia, „Wiadomości Statystyczne” 1988/5. 


\section{ENVIRONMENTAL FACTORS AFFECTING THE QUALITY OF LIFE IN RURAL AREAS ON THE EXAMPLE OF PODKARPACIE REGION}

Quality of life of residents, of both urban and rural areas, is shaped by many factors, of which the most important are: the housing situation, employment, protection of life and health, the possibility of learning and skills development, access to culture, access to retail outlets, the state of technical infrastructure and degree of satisfaction of individual needs.

Currently, the village, in addition to the preparation and delivery of food, has other features related to the protection and shaping the landscape and biodiversity, evolution of water management, conservation of cultural heritage of these areas. The article presents the results of a survey carried out in 2011 among residents of rural areas of Podkarpacie. The subjective sense of quality of life may be affected by such factors as gender, age of the person, but also the social context resulting for example from the tourist nature of the community and its position relative to the cities. The results were analyzed, broken down by municipality located near the city, away from the cities and municipalities of a tourist. The municipalities are far from towns underestimated the value of agricultural production and the purity of the environment, and the communities located near the cities emphasized the quality of roads, sewerage and water supply and rural labor market. The communities are located away from the city observed fewer differences in evaluation of environmental factors, which may indicate local consistency of seeing the world.

Keywords: quality of life, rural areas, environmental factors

DOI:10.7862/rz.2013.hss.45

Tekst złożono w redakcji: październik 2013.

Przyjęto do druku: styczeń 2014. 